\title{
Rhetorical Patterns in the Discussion Sections of Malay Research Articles
}

\author{
Chek K. Loi, M. Sweetnam Evans, S. Akkakoson, Shabbir Ahmed, and Shameem Ahmed
}

\begin{abstract}
The present study examines the communicative purposes (moves) employed in Malay research article discussions in the field of education. The analysis framework is based on the move-structure model proposed by Peacock (2002). The Malay research articles were selected from the Jurnal Pendidikan Bahasa Melayu - JPBM (Malay Language Education Journal - MyLEJ). In order to provide more comprehensive findings, specialist informants' views were obtained via email correspondences in relation to their perceptions in writing research article discussions in their discourse community. The present study has pedagogical implications in an EAP (English for Academic Purposes) classroom.
\end{abstract}

Index Terms-Academic writing, communicative purposes, Malay research articles, pedagogical implications.

\section{INTRODUCTION}

In applied linguistics, particularly in the field of English for Specific Purposes (ESP), genre is viewed as a dynamic activity in social contexts, in that genre is identified with the "socially recognized purposes" [1] or "communicative purposes" [2] generally agreed upon by members of the discourse community. Although much work has been carried out on the discussion sections of English research articles to examine disciplinary variation (e.g. [3], [4], [5]), much less has been undertaken to compare the rhetorical structure of discussion sections in Malay research articles. To the best of our knowledge, one cross-cultural genre-based study has been carried out on Malay research articles with the focus on the introduction section [6]. No published research to date has examined discussion sections of Malay research articles. The present genre-based study of Malay research article discussions should fill this small but significant gap.

A further justification for examining Malay research article discussions is the pedagogical rationale for extending past genre analyses of the introduction section to the discussion section. The findings will assist ESL (English as second language) learners to write 'good' discussion sections, which (along with the introduction section), is known to be one of the most difficult and complex sections to write [7]. According to [8], using move analyses, students can intentionally exploit the communicative functions and their linguistic features through tasks and materials similar to the

Manuscript received April 8, 2015; revised June 21, 2015. This work was supported by Universiti Malaysia Sabah under UMS research grant.

Chek K. Loi is with Universiti Malaysia Sabah, Jalan Sungai Pagar, Malaysia (e-mail: 1ck734@yahoo.com).

M. Sweetnam Evans is with University of Otago, New Zealand.

S. Akkakoson is with King Mongkut's University of Technology North Bangkok, Thailand.

Shameem Ahmad and Shabbir Ahmed are with Universiti Malaysia Sabah, Malaysia. ones which they are supposed to understand and write.

Past studies on the discussion section have identified various move-structure models. Two of the earliest studies on the discussion section are by [3] and [2]. [3] identified ten moves in the discussion section of M.Sc. dissertations and articles on irrigation and drainage published in the proceedings of an international conference. These moves include (i) background information (ii) statement of result (iii) (un)expected outcome (iv) reference to previous research (v) explanation of unexpected results (vi) exemplification (vii) deduction (viii) hypothesis (ix) recommendation and (x) justification. Similarly, the similar moves were found in [2]'s study. Swales presented the moves as follows: (i) background information, (ii) statement of results, (iii) (un)expected outcome, (iv) reference to previous research, (v) explanation, (vi) exemplification, (vii) deduction of the hypothesis and (viii) recommendation.

Based on [3]'s move-structure model of natural science discussion sections, [4] proposed a modified version of the model for humanities and social sciences discussion sections which comprises eight moves including a new move "outlining parallel or subsequent developments" which Holmes found in the concluding paragraphs of history articles. Writers of history articles employed this move to provide a "presentation in summary form of data additional to that given in the main body of the article". Moves in Holmes's model are therefore: (i) background information (ii) statement of result (iii) (un)expected outcome (iv) reference to previous research $(\mathrm{v})$ explanation of unsatisfactory result (vi) generalization (vii) recommendation and (viii) outlining parallel or subsequent developments.

In a more recent study on the discussion section (i.e. [5]), articles from seven disciplines were examined, namely physics, biology, environmental science, business, language and linguistics, public and social administration, and law using [9]'s model. [5] proposed a revised model comprising a three-part framework of move cycles of two or more of the following eight moves, namely (i) Move 1 - information move (background about theory/research aims/methodology) (ii) Move 2 - finding (with or without a reference to a graph or table) (iii) Move 3 - expected or unexpected outcome (comment on whether the result is expected or not) (iv) Move 4 - reference to previous research (v) Move 5 explanation (reasons for expected or unexpected results) (vi) Move 6 - claim (contribution to research - sometimes with recommendation for action) (vii) Move 7 - limitation and (viii) Move 8 - recommendation (suggestion for future research). The three-part framework and move cycle series are:

1) Introduction (Moves 1, or 2, or 6)

2) Evaluation (the key move cycles are $2+4,2+6,3+4$, and 
3+5. Other less common cycles are $6+4$ and $4+6)$.

3) Conclusion (Moves $2+6$, or 8 , or $8+6$, or $7+6$ ).

Ref. [5]'s model appears to display a more extensive range of communicative categories than all the other models reviewed above. The present study which examines the communicative purposes employed in Malay research article discussions uses [5]'s model as the basis for the analysis. It also attempts to relate major features or findings to possible contextual factors. The findings of the present study have pedagogical implications for Malay ESL students in an EAP (English for Academic Purposes) classroom.

\section{METHODOLOGY}

The corpus of the present study comprises the discussion sections of Malay research articles published between 2009-2014. Malay research articles were selected from the Jurnal Pendidikan Bahasa Melayu - JPBM (Malay Language Education Journal - MyLEJ) published by Universiti Kebangsaan Malaysia. The discussion section examined in this study is defined as the section found before the conclusion section and the section has to be defined only as "discussion" and not as other functional headings such as "results and discussions" or "discussion and conclusion", etc.

The list of moves as outlined in [5] model of the discussion section and the three-part framework in [5] were adopted in the present study. Some modifications were made by extending the scope of the rhetorical moves based on the findings that emerged in the present study. Categories (direct equivalents) similar to those suggested by Peacock are, namely (i) information move (ii) finding (iii) (un)expected outcome (iv) reference to previous research (v) explanation (vi) limitation and (vi) recommendation. A category which is more or less equivalent to "claim" as labelled in [5] model is "significance of the study". Two additional moves labelled as "implication of the study" and "deduction" were added to the model of the present study. The three-part framework (introduction, evaluation, and conclusion) in [5] was also adopted. A move analysis was carried out for the corpus of the present study based on the revised model. The results of the coding were subjected to a quantitative analysis on the frequency counts of Malay discussions employing the moves.

Three specialist informants' views were also obtained. They are academics who have the qualification in the field of linguistics/English language teaching/TESOL (Teaching English to Speakers of Other Languages).

\section{RESULTS AND DISCUSSION}

All the moves listed in [5] model are found in Malay discussions. Moves that occur rather frequently in the set of the discussions (at least $50 \%$ of the discussions are Move 4 (deduction) (100\% of the discussions), Move 2 (findings) (75\% of the discussions) followed by Move 5 (reference to previous research) (60\%) and Move 1 (information move) $(50 \%)$. The remaining moves are rarely used. These moves are Move 8 (implication) (20\%), Move 10 (recommendation) (20\%), Move 7 (significance of the study) (10\%), Move 9 (limitation) (5\%), Move 3 [(un) expected outcome] (5\%) and Move 6 (explanation — reasons for the expected/unexpected outcome) (5\%). The following Fig. 1 shows the above results:

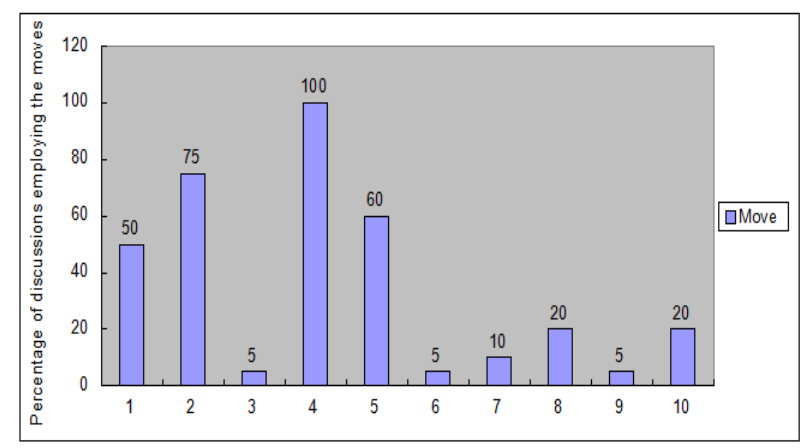

Fig. 1. Frequency counts of Malay discussions employing the moves.

In addition, rhetorical moves in the discussions are commonly realized cyclically rather than linearly or in a composite manner. It is worth noting that in past studies (e.g. [2], [3], [4], [8], [10]), the discussion section has been shown to be highly cyclical. A closer examination shows that the predictable move cycle $2+5$ (finding+reference to previous research) is the second commonly-found move in the set of discussions (in $75 \%$ of the discussions). The most frequentlyused move cycle is $4+5$ (deduction+reference to previous research) (in $90 \%$ of the discussions). Other key move cycles commonly found (in at least $55 \%$ of the discussions) in the discussions are $2+4$ (finding+deduction) (65\%), 4+2 (deduction+finding) $(55 \%)$. The following provides some examples of the above key move cycles from the corpus:

\section{Example 1}

Move cycle 4+5 (deduction+reference to previous research)

\section{M2}

Dapatan kajian menunjukkan tidak terdapat perbezaan yang signifikan antara kecerdasan emosi antara murid lelaki dan murid perempuan. [Move 4] Hasil kajian ini selaras dengan dapatan kajian lepas seperti Roshiza (2002) dalam kajiannya ...[Move 5] Dapatan kajian menunjukkan tidak terdapat perbezaan yang signifikan terhadap kecerdasan emosi antara aliran Sains dan Sastera dalam pembelajaran. [Move 4] Menurut Salovey dan Mayer (1990) ... [Move 5]

\section{M2 (translated version)}

The findings showed no significant difference in emotional intelligence between boys and girls. [Move 4] The results of this study are consistent with previous research findings such as Roshiza's (2002) study ... [Move 5] The results showed no significant difference of emotional intelligence between students from the Science and Arts streams in the learning process. [Move 4] According to Salovey and Mayer (1990) ... [Move 5]

\section{Example 2}

Move cycle 2+5 (finding+reference to previous research)

\section{M12}

Berkaitan dengan sikap guru terhadap kemahiran menulis, didapati ramai guru sangat bersetuju dan sedar bahawa melaksanakan pengajaran kemahiran menulis merupakan tanggungjawab guru ... [Move 2] Perkara ini bertepatan dengan dapatan kajian Faridah Serajul Haq dan rakan-rakan (2001) iaitu ... Dapatan tersebut turut disokong oleh dapatan kajian Jeyagobi hamodarem (2008), iaitu ... [Move 5] 
Beberapa pernyataan positif lain turut dipersetujui oleh guru-guru ... Namun demikian, ramai guru sangat tidak bersetuju dengan pernyataan matlamat mereka mengajar kemahiran menulis hanya untuk menghabiskan sukatan pelajaran sahaja... [Move 2] Pernyataan tersebut bertentangan dengan dapatan kajian Seman Salleh (2005) iaitu fokus pengajaran kepada peperiksaan menyebabkan... [Move 5]

\section{M12 (translated version)}

With regard to teachers' attitudes toward writing skills, it is found that many teachers strongly agree and realize that teachers are responsible to implement the teaching of writing skills ... [Move 2] This coincides with the findings of Faridah Serajul Haq and colleagues (2001) ... The results of these findings are also supported by Jikal hamodarem (2008), which is ... [Move 5] Some other positive statements are also agreed by the teachers ... However, many teachers strongly disagree with the statement that they aim to teach writing skills merely to complete the syllabus... [Move 2] The statement is contrary to the findings of Seman Salleh (2005) that is; the focus on examination in teaching process causes ... [Move 5]

Example 3

Move cycle 2+4 (finding+deduction)

\section{M3}

Keputusan analisis ujian-t bagi ujian pra ialah $t(52)=$ 0.394, $p>0.05$. [Move 2] Oleh itu, keputusan ini menunjukkan tidak terdapat perbezaan yang signifikan antara skor kumpulan eksperimen dan kawalan ... [Move 4] Keputusan analisis ujian-t bagi ujian pasca pula ialah $t(52)=$ 4.483, $p<0.05$. [Move 2] Keputusan ini menunjukkan bahawa terdapatnya perbezaan min prestasi pemahaman bacaan yang signifikan antara skor kumpulan eksperimen dan kawalan. Keputusan ini juga membuktikan, terdapatnya peningkatan prestasi pemahaman murid kumpulan eksperimen ... [Move 4]

\section{M3 (translated version)}

T-test analysis results for the pre-test is $t(52)=0.394, p>$ 0.05. [Move 2] Thus, these results show no significant difference between the scores of the experimental group and control group ... [Move 4] The result of the t-test analysis for post-test is $t(52)=4,483, p<0.05$. [Move 2] These results indicate that there are significant differences in the mean scores of reading comprehension performance between the experimental group and control group. These results also prove that there is an increase in the comprehension level of students from the experimental group ... [Move 4]

\section{Example 4}

Move cycle 4+2 (deduction+finding)

M17

Daripada kajian ini jelas menunjukkan bahawa responden mempunyai sikap positif terhadap pelaksanaan pembelajaran Jigsaw II. [Move 4] Responden berpendapat bahawa pembelajaran Jigsaw II dapat memberikan input yang positif kepada mereka. Dengan itu responden mengakui bahawa mereka dapat lebih banyak isi karangan apabila berbincang dengan kawan-kawan dalam kumpulan... [Move 2] Pelaksanaan pembelajaran Jigsaw II dalam pembelajaran penulisan karangan juga menunjukkan kesan yang positif terhadap pencapaian dalam penulisan karangan. [Move 4] Kajian mendapati bahawa pelaksanaan strategi pembelajaran ini meningkatkan tahap pencapaian dalam penulisan karangan responden. Ini dibuktikan menerusi ujian-t yang dijalankan ... [Move 2]

\section{M17 (translated version)}

This study clearly shows that respondents have a positive attitude towards the implementation Jigsaw II learning approach [Move 4] Respondents argue that Jigsaw II learning approach can provide them with positive inputs. Therefore, respondents admit that they can obtain more contents when engaging in a group discussion with friends ... [Move 2] The implementation of Jigsaw II technique in essay writing learning also shows a positive impact on essay writing achievement. [Move 4] The study found that the implementation of this learning strategy increased the achievement level of the respondents' essay writing. This has been proven through the conducted t-test ... [Move 2]

Move 4 (deduction) which is found to be obligatory (appearing in $100 \%$ of the discussions) in the set of discussions is commonly found to be the "head" move in a move cycle. The Malay excerpt below shows an example of cyclicity [with Move 4 (deduction) as the 'head' move], which shows the cycle of Move 4 and Move 5 recurs :The core cycle of ' $4-5$ ' suggests that different deductions (Move 4) are supported by or compared to those in the literature (Move 5):

\section{Example 5}

\section{M7}

Dapatan kajian menunjukkan bahawa tidak terdapat perbezaan skor min yang signifikan dalam kepemimpinan pengajaran guru berdasarkan faktor latar belakang guru seperti ... [Move 4 -deduction] Dapatan ini disokong oleh dapatan kajian Ritter dan Hancock (2007), dalam menentukan faktor yang mempengaruhi pengurusan kelas di sekolah ... [Move 5 - reference to past studies] Hasil analisis hubungan antara kepemimpinan pengajaran dengan sikap guru pula menunjukkan bahawa wujud hubungan yang signifikan pada tahap sederhana dan ... [Move 4-deduction] Dapatan ini sejajar dengan penjelasan Teori House (1974) dan Teori Kepemimpinan Transformasi (1997) yang membuktikan bahawa ... [Move 5- reference to past studies]

\section{M7 (translated version)}

The results show that there are no significant differences in the mean scores of the leadership of teaching based on teachers' background factors such as ... [Move 4 - deduction] This finding is supported by the findings of Ritter and Hancock (2007), in determining the factor that affects the class management in schools ... [Move 5- reference to past studies] The analysis results on the relationship between the leadership of teaching and teachers' attitudes show that there is a significant relationship at a moderate level and ... [Move 4-deduction]. This finding is consistent with the theoretical 
explanations of House Theory (1974) and Transformation Leadership Theory (1997), which prove that ... [Move 5reference to past studies]

In addition, Malay discussions tended to not conform to the concluding part of the three-part framework in [5] model in the sense that the moves labelled in the concluding part of Peacock's three-part framework were hardly found in Malay discussions. These moves are, namely Move 7 (significance of the study) [equivalent to 'claims' in Peacock's (2002) model], Move 9 (limitation) and Move 10 (recommendation).

In [5]'s suggestions for teaching move structure in the discussion section of a research article, claims (contribution to research/significance of the study), limitation and recommendation are the three significant moves to be taught to NNS (non-native speakers of English) students/authors. They are also the three important moves/communicative purposes to be included in the discussion section of a research article as reflected in the following specialist informants' views:

A good discussion is logically organized, points considered stem from the previous ones or are interconnected. Personal contribution is really relevant, though it must be consistently motivated on the grounds of your own research and previous studies conducted by other specialists in the field. For example, you cannot just state "My view is that or this" you must defend coherently your thesis ... (Informant B) ... and - most importantly - how you see your material your analysis - and how it furthers the field of study. And to show where your claims/propositions/arguments might be wrong. (Informant $\mathrm{R}$ )

A good discussion section of a research paper would outline current thinking in the field your paper focuses on (multiple perspectives) and highlight areas of potential conflict in the future as brought to light by the research undertaken. This is the discursive norm. Other approaches might be epistemologically-driven... I.E. post-modern efforts... Feminist theory etc. (Informant T)

\section{CONCLUSION}

The present findings have some pedagogical implications in an EAP classroom, The move structure model that emerged in the present study will be worth exploring with language instructors and ESL students (Malay ESL students in particular) in EAP classrooms. Students however need to be made aware that the list is not exhaustive and the conventions of research writing can differ across disciplines. Because a relatively small corpus was used (20 discussions), the present study does not aim to generalize the findings to an entire discipline. Far more genre-based research involving the Malay language needs to be undertaken for research article discussions in the field of education in order to develop our knowledge of the rhetorical moves and key move cycles.

\section{ACKNOWLEDGMENT}

This paper is part of a larger research. We would like to thank the panel members' views and feedback on this paper at the PPIBKAL seminar. Our deep appreciation also goes to the specialist informants (Boryana, Rod and Tristan) for the present study.

\section{REFERENCES}

[1] V. K. Bhatia, Analysing Genre; Language We Use in Professional Settings, London: Longman, 1993.

[2] J. M. Swales, Genre Analysis. English in Academic and Research Settings, Cambridge, UK: Cambridge University Press, 1990.

[3] A. Hopkins and T. Dudley-Evans, "A genre-based investigation of the discussion sections in articles and dissertations," English for Specific Purposes, vol. 7, pp. 113-122, 1988.

[4] R. Holmes, "Genre analysis and the social sciences: An investigation of the structure of research article discussion sections in three disciplines," English for Specific Purposes, vol. 16, pp. 321-337, 1997.

[5] M. Peacock, "Communicative moves in the discussion section of research articles," System, vol. 30, pp. 479-497, 2002.

[6] U. K. Ahmad, "Scientific research articles in Malay: A situated discourse analysis," Ph.D. dissertation, University of Michigan, 1997.

[7] N. K. Mirahayuni, "Investigating textual structure in native and non-native English research articles: Strategies differences between English and Indonesian writers," Ph.D. dissertation, University of New South Wales, 2002.

[8] P. Brett, "A genre analysis of the result section of sociology articles," English for Specific Purposes, vol. 13, pp. 47-59, 1994.

[9] T. Dudley-Evans, "Genre analysis: An approach to text analysis for ESP," Critical Discourse Analysis, London: Longman, 1994.

[10] R. Yang and D. Allison, "Research articles in applied linguistics: Moving from results to conclusions," English for Specific Purposes, vol. 22, pp. 365-385, 2003.

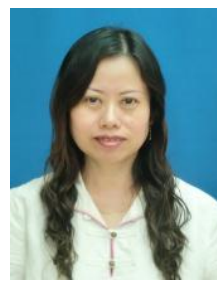

Chek K. Loi is presently a senior lecturer at Universiti Malaysia Sabah. She obtained her $\mathrm{PhD}$ degree in linguistics from University of Otago, Dunedin, New Zealand in 2011. She pursued her postdoctoral program in the United Kingdom in 2014. She has published papers in some international journals, namely Journal of Pragmatics, Journal of English for Academic Purposes. Her research interests include genre analysis, intercultural communication, bilingualism and discourse analysis.

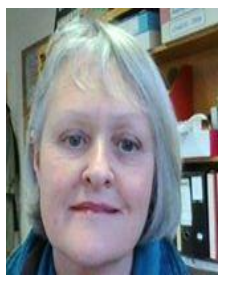

Moyra Sweetnam Evans is presently a senior lecturer at the English and Linguistics Department, University of Otago, New Zealand. She obtained her PhD degree from University of Johannesburg in 1995. She has published many books and chapters, journal articles and refereed conference proceedings. Her research expertise include reading, comprehension, narrative, bilingual reading, TESOL, stylistics, writing, and rhetorical style.

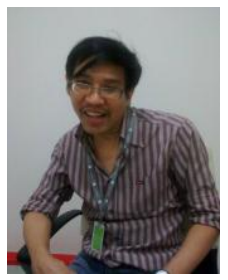

Songyut Akkakoson is an assistant professor of English at the Department of Languages, Faculty of Applied Arts, King Mongkut's University of Technology North Bangkok, Thailand. He obtained his $\mathrm{PhD}$ degree in applied linguistics from University of Otago, New Zealand. His research interests lie in learning styles, learning strategies, reading in EFL, English for business communication, English speaking anxiety, ESP genre analysis and world Englishes.

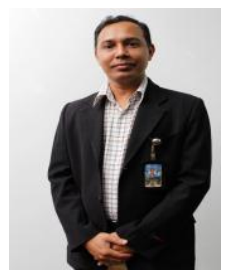

Shabbir Ahmed is currently working as a lecturer for English language courses in UMS, Labuan Campus. $\mathrm{He}$ obtained an MA degree in English language teaching. His research interests are academic research and writing, discourse and genre analysis, etc. Currently, he is working on a book entitled "A Handbook on Passive Voice."

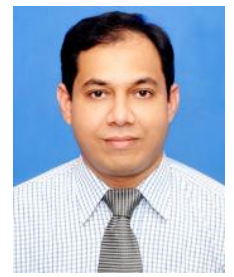

Shameem Ahmed was born in Dhaka, Bangladesh in June 20, 1970. He has got an MA degree in English, from Bangladesh and has more than fifteen years teaching experience as an EFL/ESL instructor. He has attended a few international ELT conferences in Malaysia and published a few articles. He is currently working as a lecturer (English) at University Malaysia Sabah, Labuan International Campus. His research interests include materials development, EFL reading, popular fiction, stylistics and business English. 